\title{
Shared Responsibility and Non-State Terrorist Actors
}

\author{
Kimberley N. Trapp*
}

\begin{abstract}
International law presently addresses the unique challenge to international peace and security posed by trans-national terrorism through two frameworks of responsibility: first, individual criminal responsibility; second, state responsibility. These two frameworks of responsibility are not mutually exclusive and this article develops an analytic framework for shared responsibility in the terrorism context. The framework reveals that (i) in most cases of potential shared responsibility, two sets of actors (states and non-state terrorist actors) contribute separately to a harmful outcome; (ii) in cases where the terrorist conduct of nonstate terrorist actors is not attributable to a state, the nature of the wrongful act committed is different, even if the responsibility is shared; and (iii) where there is shared responsibility, the nature of responsibility which attaches to the wrongful acts of these distinct actors is itself different (criminal vs civil or delictual). This article further explores some of the difficulties in the interpretation and practical application of both the primary and secondary rules of international law which undermine the potential for shared responsibility in the terrorism context, or worse, are a recipe for no responsibility at all. It concludes with some alternative approaches to interpretation and application to address those difficulties.
\end{abstract}

Keywords: Terrorism; Non-state actors; Individual criminal responsibility; State responsibility; Terrorism Suppression Conventions; Attribution.

\section{Introduction}

Trans-national terrorism is far from a new problem, and it often eschews the more new-

\footnotetext{
* Senior Lecturer in Public International Law; UCL, Faculty of Laws. E-mail: k.trapp@ucl.ac.uk. This article is part of the collection of articles on Organised Non-State Actors, edited by Jean d'Aspremont, André Nollkaemper, Ilias Plakokefalos and Cedric Ryngaert. The collection was organised with support of the research project on Shared Responsibility in International Law (SHARES) at the Amsterdam Center for International Law (ACIL) of the University of Amsterdam, the Utrecht Centre for Accountability and Liability Law, and the Leuven Centre for Global Governance Studies. All websites were last accessed on 15 February 2015.
} 
fangled solutions applicable to other non-state actors addressed in this symposium. Unlike some of those actors, terrorist actors operate outside the international normative legal order. There is no movement by terrorist groups to self-regulate through 'strengthening standards and commitments by both non-state actors and states, coupled with supervisory mechanisms'. ${ }^{1}$ Multi-national corporations $(\mathrm{MNCs})^{2}$ and private military companies (PMCs), ${ }^{3}$ for instance, are incentivised to some degree to be seen to be meeting the 'legitimate normative expectations of the international community', ${ }^{4}$ whether they are animated by profit or legitimacy concerns. Non-state terrorist actors (NSTAs), on the other hand, deliberately defy the international community's normative expectations, particularly by viewing human life as instrumental (and sacrifice-able) in their efforts to re-shape the rules which govern them. ${ }^{5}$

International law presently addresses the unique challenge to international peace and security posed by trans-national terrorism through two frameworks of responsibility. First, individual criminal responsibility. The international community has long addressed the problem of terrorism in reliance on a criminal law enforcement paradigm, through the elaboration of a series of Terrorism Suppression Conventions (TSCs). ${ }^{6}$ Second, international law addresses trans-national terrorism through a state responsibility paradigm. In particular, both the primary rules of international law (in states' obligations to prevent and punish terrorism under the TSCs and relevant Security Council Resolutions and to refrain from supporting or

\footnotetext{
${ }^{1}$ D’Aspremont et al. 2015, section 5.3.

${ }^{2}$ See Karavias 2015.

${ }^{3}$ See MacLeod 2015.

${ }^{4}$ D'Aspremont et al. 2015, section 2.

${ }^{5}$ Non-state armed groups participating in an armed conflict, addressed in Veronika Bílková's contribution to this symposium (see Bílková 2015), can fall somewhere in the middle of this spectrum, in that some will be driven by legitimacy concerns (for instance several non-state armed groups fighting against Assad's regime in Syria have received training in the law of armed conflict), while others like Daesh (also known as Isis) acting in Syria and Iraq resemble in many respects a terrorist group, in both structure and agenda. Where the conduct of such armed groups is regulated by the law of armed conflict, they are excluded from the scope of this article. The reason for the exclusion is that the terrorism suppression treaty regime which addresses conduct that might form part of a military campaign (like bombings, use of nuclear weapons, and acts against the safety of civil aviation and maritime navigation) exclude conduct carried out by armed forces in the context of an armed conflict (both international and non-international) from their scope. The exclusion is intended to preserve the integrity of IHL and the balances achieved therein between military necessity and humanitarian principles. See Trapp 2014.

${ }^{6}$ The multi-lateral response to trans-national terrorism takes the form of ten TSCs, each requiring state parties to (i) criminalise a particular manifestation of international terrorism (for example hijacking or shipjacking, hostage taking, terrorist bombing); (ii) co-operate in the prevention of that terrorist act in their territories, and (iii) extradite or submit terrorist actors to prosecution. The full list of TSCs can be found at the United Nations Treaty Collection website, see http://treaties.un.org/Pages/DB.aspx?path=DB/studies/page2_en.xml. For purposes of illustration, this article will rely on the International Convention for the Suppression of Terrorist Bombings, New York, 15 December 1997, in force 23 May 2001, 2149 UNTS 256 (Terrorist Bombing Convention) and the International Convention for the Suppression of the Financing of Terrorism, New York, 9 December 1999, in force 10 April 2002, 2178 UNTS 197 (Terrorism Financing Convention).
} 
participating in acts of terrorism under the United Nations (UN) Charter) and the secondary rules of international law (in particular in the form of rules on attribution) provide a framework for state responsibility in the terrorism context.

These two frameworks of responsibility are not mutually exclusive, and can form the basis of shared responsibility. ${ }^{7}$ Section 2 below develops an analytic framework for shared responsibility $^{8}$ in the terrorism context. In particular, section 2 will explore how shared responsibility is based on the terrorist related activity of different sets of actors -NSTAs, even if acting as members of an organised group, ${ }^{9}$ on the one hand, and states on the other. The framework reveals that (i) in most cases of potential shared responsibility, these different actors contribute separately to a harmful outcome (in the form of a terrorist attack or impunity for a terrorist attack), although where the terrorist conduct of the NSTAs is attributable to the state, the conduct is considered to be both that of the state and the NSTAs; (ii) in cases where the terrorist conduct of NSTAs is not attributable to a state, the nature of the wrongful act committed is different, even if the responsibility is shared; and (iii) where there is shared responsibility, the nature of responsibility which attaches to the wrongful acts of these distinct actors is itself different (criminal vs civil or delictual).

\footnotetext{
${ }^{7}$ It is obvious that states may be responsible for terrorism related wrongs, each as discussed further below in section 2, as a matter of international law. In order that there be shared responsibility in international law, individual criminal responsibility for terrorism has to also exist as a matter of international law (even if the mechanisms for enforcing that responsibility or giving effect to that responsibility are purely domestic). Each of the TSCs defines a terrorist offence as a matter of international treaty law, and then imposes enforcement obligations on states (which enforcement obligations must be given effect to within that state's domestic legal system). The TSCs also oblige states to establish universal jurisdiction over the defined terrorist offences. The combined effect of defining terrorism as a crime under treaty law, and ensuring that individual terrorists 'travel' with their responsibility if they leave a territory which has not given effect to the criminal law enforcement obligations under the TSCs and enter a territory which has, is that the criminal responsibility is international (even if given effect to through domestic legal systems). To put this another way, as with international crimes under customary international law, it is no defence to claims of individual criminal responsibility that the individual acted within, or is a national of, a state which is not a state party to the relevant TSC or has failed to implement its obligations thereunder. The responsibility is international, whether or not it is also domestic.

${ }^{8}$ The definition of shared responsibility in this article is adopted from the article introducing this symposium: 'situations where a multiplicity of actors [non-state actors and states] contributes towards a single harmful outcome that is not causally divisible'. D’Aspremont et al. 2015, section 2.

${ }^{9}$ While individual terrorist actors are often members of a 'terrorist group', terrorist groups need to be distinguished from the other organised non-state actors addressed in this symposium. Terrorist groups, however structurally organised, are defined by shared objectives more than they are by shared bank accounts held in the group's name. Terrorist 'groups' are not independent legal persons - they are to be distinguished from MNCs or PMCs, which are incorporated within at least one domestic legal system, giving rise to the possibility of relying on domestic (rather than international) dispute settlement mechanisms in seeking reparations. In addition, international law does not impose primary obligations on terrorists qua group (as is the case in respect of armed groups participating in armed conflicts). As a result, there is little benefit in addressing terrorist activity through an 'organised group' paradigm and this article will instead address terrorist actors as individuals rather than as members of a group.
} 
While the framework set out in section 2 makes it clear that there is potential for shared responsibility in the terrorism context, that potential is not often actualised in practice for a number of reasons. Section 3 will explore difficulties in the interpretation and practical application of both the secondary rules (in the form of the rules on attribution) and primary rules (in the form of state obligations to prevent and punish acts of terrorism by NSTAs) which undermine the potential for shared responsibility, or worse, are a recipe for no responsibility at all.

In particular, section 3.1 argues that the standard of attribution, developed in a context very different from that of state participation in terrorism, is overly strict in a way that undermines the likelihood that states will be held directly responsible for their participation in terrorist acts. The argument about responsibility in this case is a normative one - that the rules which establish an essential element of state responsibility (attribution) do not sufficiently allow for a finding of responsibility for participation in terrorism. The result is not that there is no possibility for shared responsibility - the state might still be held responsible for its independent acts in relation to (but separate from) the act of NSTA terrorism (for instance support for NSTA terrorism), while the individual NSTAs can be held individually criminally liable. It is rather that the possibility of shared responsibility in perhaps its purest form where different actors contribute jointly to a single harmful outcome and are held responsible for breach of the same norm - is undermined.

Section 3.2 will explore the limitations of the state responsibility paradigm in the face of failed or weak states, given that some primary rules (in particular the obligation to prevent) are territorially limited and conditioned by a diligence standard of conduct. These limitations of course affect the possibilities for shared responsibility. Where a state's factual failure to meet its prevention obligations creates the space for NSTAs to carry out acts of terrorism, the NSTAs can be held criminally responsible for their acts, even if the state might not be legally responsible (as a result of the application of the territorial limitation and due diligence standard) for its failure to prevent. This is despite the fact that the conduct of both the state and NSTAs separately and factually contributed to a single harmful outcome.

Finally, section 3.3 will explore the possibility that the aut dedere aut judicare obligation, tempered as it is by respect for a sphere of state discretion in domestic criminal law matters, might be a recipe for no responsibility at all (individual criminal, state responsibility or shared). First, the aut dedere aut judicare obligation may be a recipe for no legal 
responsibility on the part of a state. This is because the obligation recognises a margin of discretion that is broad enough to allow for lawful non-prosecution - even in cases where an NSTA within that state's territory has committed an act of terrorism. That recipe for no legal responsibility on the part of a state may then translate into no criminal responsibility for NSTAs (although in a practical, rather than legal sense). This is because NSTA legal responsibility is given effect to through a state's exercise of its domestic criminal law jurisdiction. When a state fails to exercise that domestic criminal law jurisdiction (in the form of extradition or prosecution), but that failure is not internationally wrongful (for example, because of a lack of evidence), the individual is - as a practical matter - not held criminally responsible while he or she remains in the territory of that state.

This article concludes (in section 4) with some remarks on the potentialities for shared responsibility in the terrorism context, reflecting on the challenges explored in section 3.

\section{Analytic framework for shared responsibility in the terrorism context}

In the terrorism context, shared responsibility takes the form of international responsibility on the part of the state and individual criminal responsibility (given effect to through domestic criminal law enforcement machinery) on the part of the individual NSTAs. While responsibility may be shared, it is of a different nature. State responsibility is civil or delictual in nature. ${ }^{10}$ Its focus is restorative, both in the sense of being instrumental in restoring a legal relationship between wrongdoing state and injured state or party, and in the sense of

\footnotetext{
${ }^{10}$ The possibility of state criminal responsibility for the perpetration of international crimes was long contemplated by the International Law Commission (ILC) in its codification project on state responsibility (see Garcia-Amador FV, 'Second Report on international responsibility', UN Doc. A/CN.4/106, ILC Yearbook 1957/II, p. 104, p. 105; Ago R, 'Sixth report on state responsibility': The internationally wrongful act of the State, source of international responsibility, UN Doc. A/CN.4/302 and Add. 1, 2 and 3, ILC Yearbook 1977/II(1), p. 3; and generally Jørgensen 2000). But the difficulties involved in giving effect to a regime of criminal responsibility between sovereign and equal states (including the absence of an appropriate institutional infrastructure to implement the criminal responsibility of states, the impact of such responsibility on the still developing regime of individual criminal responsibility under international law, and the form sanctions might take in the event of such responsibility) resulted in the "“depenalisation" of State responsibility' within the framework of the ILC Articles on State Responsibility (Crawford 2002, p. 36). The concern that certain breaches of international law are more serious than others, which was initially framed in terms of state crimes, was addressed through provisions in the ILC Articles on Responsibility of States for Internationally Wrongful Acts, ILC Yearbook 2001/II(2) (ARSIWA or Articles on State Responsibility), relating to serious breaches of peremptory norms and breaches of international obligations owed to the international community as a whole. See Articles 40, 41 and 48 of the ARSIWA and Crawford 2010. On the abandonment of the vocabulary of criminal law in reference to serious breaches of obligations 'essential for the protection of fundamental interests of the international community’, see Pellet 1999; Pellet 2010.
} 
reparations. ${ }^{11}$ Criminal responsibility on the other hand is evidently punitive (and potentially deterrent) in nature.

Even if always different in nature, responsibility for terrorism can be triggered by breach of the same or different norms binding on the different actors, as considered below. In every case of shared responsibility, however, NSTAs will have breached the prohibition on participation in terrorist acts. The prohibition exists as a matter of international law, even if criminal responsibility for breach of the prohibition is given effect to through states' compliance with their TSC obligations to criminalise particular manifestations of terrorist conduct (including hostage takings, crimes against internationally protected persons, crimes against the safety of international aviation and maritime navigation, terrorist bombings and acts of nuclear terrorism) $)^{12}$ and to extradite or prosecute individuals having engaged in such conduct.

There are several elements which might demarcate or categorise the different possibilities for shared responsibility in the terrorism context: whether the contribution to a single harmful outcome by the different actors (NSTAs and states) is before the fact or after the fact; whether the nature of the act which contributes to a single harmful outcome by the different actors is the same or separate; ${ }^{13}$ or whether those contributions are in breach of the same or different norms. The resulting permutations of shared responsibility in the terrorism context are explored below and represented in a matrix at the end of this section.

\subsection{Same contribution to a single harmful outcome before the fact}

Where a state directly participates in an act of terrorism (through the mechanic of attribution which ties the activity of NSTAs to the state), ${ }^{14}$ the state's contribution to the terrorist conduct is at least co-extensive with that of the NSTA. ${ }^{15}$ In such cases, shared responsibility results from both actors making the same contribution to a single harmful outcome. The responsibility of the different actors is for breach of the same norm in that both the NSTAs and the state breach the prohibition on the participation in terrorist acts. While the norm is the same, the material source of the prohibition is potentially different. States are prohibited from

\footnotetext{
${ }^{11}$ Crawford 2002, p. 19.

${ }^{12}$ See e.g. Article 4 Terrorist Bombing Convention; Article 4 Terrorism Financing Convention.

${ }^{13}$ D'Aspremont et al. 2015, section 5.1.
} 
engaging in acts of terrorism as a specific instantiation of the prohibition on the use of force under Article 2(4) of the UN Charter ${ }^{16}$ and potentially under the TSCs, ${ }^{17}$ while the material source of the prohibition binding on NSTAs is the TSCs only.

\subsection{Separate contributions to a single harmful outcome, before and after the fact}

Shared responsibility in the terrorism context can also be 'assessed on the basis of independent acts of these actors [NSTAs and states]'; ${ }^{18}$ in that NSTAs and states separately contribute to a single harmful outcome (in the form of an act of terrorism, or impunity for an act of terrorism).

These separate contributions to a single harmful outcome take the form of a breach of different norms by NSTAs and states, and arise where the conduct of the NSTA is not attributable to the state. In such cases, an NSTA can be held criminally responsible for terrorist conduct (in breach of the prohibition against such participation), but the state is held delictually responsible for its failure to act appropriately in relation to the terrorist conduct of NSTAs either before (failure to diligently prevent the conduct) ${ }^{19}$ or after (failure to extradite or submit the NSTA to prosecution) the fact. ${ }^{20}$ It bears noting that in cases of a failure to prevent or punish, not every terrorist act results in shared responsibility, or indeed any responsibility at all. As set out in the matrix below and discussed further in sections 3.2 and 3.3, it is possible for states to factually fail to prevent or to extradite/prosecute an act of

\footnotetext{
${ }^{14}$ There is also, of course, the possibility that a state might carry out terrorist activities through its own organs, rather than through NSTAs whose conduct is attributable to the state but who nevertheless remain outside the formal de jure structure of the state. This was for instance the situation in the infamous Rainbow Warrior case (1986, see n. 66). On terrorist activities by state organs, and the Rainbow Warrior case in particular, see Trapp 2011, §2.2.1.

${ }^{15}$ This is the case even if the state's actions go beyond those of the NSTAs, through its direction, control or material support of the terrorist act.

${ }^{16}$ See Trapp 2011, §2.1. Charter of the United Nations, San Francisco, 26 June 1954, in force 24 October 1945, 1 UNTS 16 (UN Charter).

17 The prohibition of state participation in terrorism might be read into the TSCs through the obligation to prevent, on the basis of a Bosnian Genocide case analysis, resulting in both the norm and the material source of the norm binding on NSTAs and states partially overlapping (in that NSTAs are not bound by the UN Charter). See Trapp 2012.

${ }^{18}$ D’Aspremont et al. 2015, section 5.1.

${ }^{19}$ See Corfu Channel case (United Kingdom of Great Britain and Northern Ireland v. Albania), Merits, ICJ Reports 1949, p. 4, p. 22. See also the ILC's survey of international law in relation to its work of codification, UN Doc. A/CN.4/1/Rev.1 (1949), p. 56, para. 97, referring to 'failures to prevent the use of national territory as a base for acts noxious to the legitimate interests of neighbouring states' as one of the central problems of state responsibility calling for elucidation. The obligation to prevent is also set out in all the TSCs. See for example Article 15 Terrorist Bombing Convention; Article 18 Terrorism Financing Convention.

${ }^{20}$ The aut dedere aut judicare obligation in the TSCs is a creature of treaty law. See Trapp 2011, §3.2.1.
} 
terrorism, for which failure they are not legally responsible. In such cases, there may well be individual criminal responsibility (provided, in the case of one state's failure to extradite or prosecute, that another state does in fact meet this obligation) without any state responsibility - and therefore no shared responsibility either.

Assuming a terrorist attack has in fact been committed by NSTAs, the resulting matrix of shared responsibility in the terrorism context is set at the end of this section.

\subsection{Relationship between NSTA and state responsibility for terrorism}

Even when shared, NSTA and state responsibility for acts of terrorism are given effect to in distinct legal orders (the one domestic, the other international), and each is therefore established independently from the other. ${ }^{21}$ In practice, however, the relationship between the two forms of responsibility is significantly more dynamic, particularly where shared responsibility is the result of a state's direction or control of an act of terrorism carried out by NSTAs (state act A, matrix below). For instance, determinations of individual criminal responsibility in domestic proceedings can catalyse a victim state into formally invoking a wrongdoing state's responsibility and taking measures against the wrongdoing state to enforce that responsibility, particularly where determinations of state agency (attribution) were part of the domestic determination of guilt. ${ }^{22}$ The initiation or conclusion of a domestic criminal process may also serve to pressure wrongdoing states into accepting the secondary obligations which flow from their responsibility, again most particularly where the domestic court has made factual determinations as to the relationship between NSTA and a state. ${ }^{23}$ Given this relationship, injured states tend to pursue the criminal model of responsibility for terrorism before (if ever) invoking state responsibility. The international community (through the

\footnotetext{
${ }^{21}$ See Application of the Convention on the Prevention and Punishment of the Crime of Genocide (Bosnia and Herzegovina v. Serbia and Montenegro), Judgment, ICJ Reports 2007, p. 43, paras. 180-182; Selmouni v. France, Judgment of 28 July 1999, European Court of Human Rights (2000) 29 EHRR 403, §87. See also Nollkaemper 2008, pp. 353-354.

22 See Trapp 2011, §6.1, for a discussion of invocations of state responsibility following from criminal convictions by domestic courts in which the domestic courts made findings as to the connection between the individual terrorist actors and states directing or supporting their activities.

${ }^{23}$ See below n. 66 and discussion of the La Belle Disco bombing, the Rainbow Warrior bombing and the Lockerbie bombing. See further, Trapp 2011, §6.2.
} 
Security Council) also tends to prioritise securing individual criminal responsibility, rather than state (and resulting shared) responsibility, for acts of terrorism. ${ }^{24}$

That said, domestic or international criminal courts, practiced in evaluating complicated evidence (more so than is the International Court of Justice (ICJ or Court)), can play a decisive role in the judicial settlement of disputes regarding state responsibility for terrorism, giving better effect to shared responsibility. For instance, in the Bosnian Genocide case, the ICJ relied heavily on determinations of fact by the International Criminal Tribunal for the Former Yugoslavia (ICTY) in its judgment on Serbian responsibility for genocide. ${ }^{25}$ While legal determinations of state responsibility are clearly beyond the jurisdiction of criminal courts (whether domestic or international), the factual basis of a determination of individual criminal responsibility will often involve an assessment of the capacity in which an individual terrorist acted (including whether such person acted as an agent of the state). In anticipation of the use to which such determinations might be put by international courts addressing state responsibility for terrorism, ${ }^{26}$ domestic or international criminal courts should ensure that their judgments on criminal responsibility for terrorism are very clear in respect of the factual relationship between individual terrorist actors and states.

\section{Table 1 Matrix of shared responsibility in the terrorism context}

\footnotetext{
${ }^{24}$ For instance, in regard to the Lockerbie bombing and the attempted assassination of Mubarak in Ethiopia (1995), the UN Security Council qualified failures to comply with extradition or transfer requests as threats to international peace and security and focused its energy on ensuring those responsible for the attacks were brought to criminal justice. See UN Doc. S/RES/748 (31 March 1992); UN Doc. S/RES/1054 (26 April 1996); and UN Doc. S/RES/1070 (16 August 1996).

${ }^{25}$ Bosnian Genocide case, paras. 374-375.

${ }^{26}$ The ICJ would have jurisdiction over questions of state sponsored or supported terrorism pursuant to the TSC compromissory clauses on the basis of a Bosnian Genocide case approach. See Trapp 2012.
} 


\begin{tabular}{|c|c|c|c|}
\hline & State act & $\begin{array}{l}\text { Shared } \\
\text { responsibility? }\end{array}$ & $\begin{array}{l}\text { Trigger for } \\
\text { responsibility }\end{array}$ \\
\hline $\begin{array}{l}\text { Same contribution } \\
\text { to a single harmful } \\
\text { outcome before the } \\
\text { fact }\end{array}$ & $\begin{array}{l}\text { State act A: } \\
\text { Attributable } \\
\text { conduct }^{27}\end{array}$ & Yes & $\begin{array}{l}\text { Breach of the same } \\
\text { norm (prohibition on } \\
\text { participation in acts } \\
\text { of terrorism), } \\
\text { although source of } \\
\text { norm may be } \\
\text { different. }\end{array}$ \\
\hline \multirow[t]{2}{*}{$\begin{array}{l}\text { Separate } \\
\text { contribution to a } \\
\text { single harmful } \\
\text { outcome before the } \\
\text { fact }\end{array}$} & \multirow[t]{2}{*}{$\begin{array}{l}\text { State act B: Failure to } \\
\text { prevent terrorist acts } \\
\text { by NSTAs }{ }^{28}\end{array}$} & $\begin{array}{l}\text { Maybe } \\
\text { Factual failure to } \\
\text { prevent NSTA } \\
\text { terrorism despite } \\
\text { diligent effort = } \\
\text { no shared } \\
\text { responsibility } \\
\text { (individual criminal } \\
\text { responsibility but no } \\
\text { state responsibility) }\end{array}$ & $\begin{array}{l}\text { NSTA breaches } \\
\text { prohibition on } \\
\text { participation in acts } \\
\text { of terrorism. }\end{array}$ \\
\hline & & $\begin{array}{l}\text { Failure of diligence } \\
\text { in terrorism } \\
\text { prevention efforts } \\
= \\
\text { shared responsibility }\end{array}$ & $\begin{array}{l}\text { Breach of a different } \\
\text { norm. States breach } \\
\text { obligation to } \\
\text { diligently prevent } \\
\text { terrorism; NSTAs } \\
\text { breach prohibition on } \\
\text { participation in acts } \\
\text { of terrorism. }\end{array}$ \\
\hline
\end{tabular}

\footnotetext{
${ }^{27}$ See section 3.1 below.

${ }^{28}$ A state's support for NSTAs (which support is material but does not rise to the level required for attribution noted in 'state act $\mathrm{A}$ ' and discussed further in section 3.1 below) would also be an example of a separate contribution to a single harmful outcome before the fact. Shared responsibility for such support would be based on breach of different norms: the state held responsible for breaching the prohibition on support for acts of terrorism (a further specific instantiation of the prohibition on the use of force in Article 2(4) of the UN Charter, see Trapp 2011, §2.1.2) and the NSTA held responsible for breaching the prohibition on participation in acts of terrorism. As this particular form of shared responsibility is less problematic than those discussed further below, it is not addressed in any particular detail in this article.

${ }^{29}$ See section 3.2 below.
} 


\begin{tabular}{|c|c|c|c|}
\hline & State act & $\begin{array}{l}\text { Shared } \\
\text { responsibility? }\end{array}$ & $\begin{array}{l}\text { Trigger for } \\
\text { responsibility }\end{array}$ \\
\hline \multirow[t]{2}{*}{$\begin{array}{l}\text { Separate } \\
\text { contribution to a } \\
\text { single harmful } \\
\text { outcome after the } \\
\text { fact }\end{array}$} & \multirow[t]{2}{*}{$\begin{array}{l}\text { State act C: Failure to } \\
\text { extradite or prosecute } \\
\text { NSTA }\end{array}$} & $\begin{array}{l}\text { Maybe } \\
\text { Factual failure to } \\
\text { punish terrorism } \\
= \\
\text { no shared } \\
\text { responsibility } \\
\text { (individual criminal } \\
\text { responsibility but no } \\
\text { state responsibility) }^{30}\end{array}$ & $\begin{array}{l}\text { NSTAs breach } \\
\text { prohibition on } \\
\text { participation in acts } \\
\text { of terrorism }\end{array}$ \\
\hline & & $\begin{array}{l}\text { Culpable failure to } \\
\text { punish terrorism } \\
= \\
\text { shared responsibility }\end{array}$ & $\begin{array}{l}\text { Breach of a different } \\
\text { norm. States breach } \\
\text { obligation to punish } \\
\text { terrorism; NSTAs } \\
\text { breach prohibition on } \\
\text { participation in acts } \\
\text { of terrorism. }\end{array}$ \\
\hline
\end{tabular}

\section{Challenges for shared responsibility in the terrorism context}

Given the current focus on the individual criminal responsibility of terrorist actors discussed in section 2 above, shared responsibility rarely arises, even where there are serious allegations of state involvement in, or failures in respect of, terrorist acts by NSTAs. There are a number of possible reasons for the international community's failure to make use of the regime of state responsibility in the terrorism context - in addition to its reliance on an individual criminal responsibility paradigm - which use would result in shared responsibility. This article will address three difficulties in the interpretation and practical application of the primary and secondary rules of international law which stand in the way of ensuring that both NSTA and state parties which are factually responsible for contributing to a single harmful terrorist outcome are held legally responsible for that contribution.

The analysis below will track the possibilities for shared responsibility set out in the matrix in section 2, first assessing the responsibility gap which emerges as a result of the overly strict definition of standards of attribution (state act A, matrix above/section 3.1 below); second examining the real world limitations of the primary obligation to prevent terrorism as a recipe

\footnotetext{
${ }^{30}$ See section 3.3 below.
} 
for state responsibility (state act B, matrix above/section 3.2 below); and concluding with an exploration of the legal limitations of an obligation to extradite or prosecute, which limitations might be a recipe for no responsibility at all (state act C, matrix above/section 3.3 below).

\subsection{The ICJ's strict approach to Article 8 attribution}

Despite infamous cases like the Rainbow Warrior bombing (in which France relied on its own organs to carry out an act of terrorism), states are most likely to participate in terrorist activities through non-state actors who act on their behalf while remaining outside the formal structure of the state. ${ }^{31}$ When the relationship between the state and the NSTAs carrying out the terrorist act rises to the level of attribution, shared responsibility between the NSTAs and the state for breach of the same norm arises. Indeed, where attribution is present, these different actors do not contribute separately to a harmful outcome, as the relevant terrorist conduct is considered to be both that of the state and the NSTAs. This is so even though the state's actions will have gone beyond those of the NSTAs (in that, in addition to having carried out the act of terrorism through the mechanic of attribution, the state will also have directed or controlled the NSTAs). Both the NSTAs and the state are held responsible for breach of the prohibition on the participation in terrorist acts - even though that responsibility is of a different nature (in that the individual is held criminally responsible while the state is held delictually responsible).

Whether such shared responsibility can be given effect to, however, depends in part on the extent to which the legal standard of attribution reflects the realities of the terrorism context. The applicable standard of attribution - instructions, direction or control - is set forth in Article 8 of the Articles on State Responsibility. It is worth noting that Article 8 requires 'control' pure and simple - without specifying the degree of control necessary for attribution, and states have read Article 8 in a way which leaves room for an adaptable application. ${ }^{32}$ Flexible approaches to 'control' under Article 8 of the Articles on State Responsibility have

\footnotetext{
${ }^{31}$ See Hoffman 2006, p. 27; Byman 2005, chapter 2.

32 The Netherlands suggested that Article 8 ARSIWA allows for a flexible standard of control and that this inbuilt ambiguity offers scope for progressive development. ILC, Comments and observations received from Governments on State Responsibility, UN Doc. A/CN.4/515 (2001), 23. Similarly, members of the ILC suggested that varying degrees of sufficient control were required in different legal contexts. Report of the ILC on the work of its fiftieth session, UN Doc. A/53/10 and Corr.1 (1998), 395. See also Dupuy 2004, p. 10.
} 
also been adopted in some international dispute settlement contexts. ${ }^{33}$ Nevertheless, the ICJ suggested in its Bosnian Genocide case decision that a strict 'effective control' approach, derived from its decision in Nicaragua, ${ }^{34}$ is the only one it will take to Article 8 attribution. ${ }^{35}$ The difficulty with the 'effective control' test, as articulated in Nicaragua, is that it is entirely inapposite to the terrorism context. The test was driven by the particular factual matrix in Nicaragua (also evident in the Bosnian Genocide case) - a factual matrix which is missing in regard to terrorist crimes (as defined in the TSCs, which exclude acts committed by armed forces during the course of an armed conflict). In Nicaragua and the Bosnian Genocide case, the Court was addressing state support for paramilitary operations during the course of which international crimes were committed (war crimes and genocide respectively). In each case, international crimes were a non-inherent feature of the paramilitary operations, and the state's objectives in supporting the paramilitary operations were ostensibly other than the commission of such international crimes. As a result of these very particular facts, the Court held that the state would only be responsible for the international crime, by way of attribution, if the 'State had effective control of the military and paramilitary operations in the course of which the alleged violations were committed'. ${ }^{36}$

In the terrorism context, however, there is no non-inherent feature of a broader campaign the supported use of force is the terrorist operation (not an incidental feature). It is difficult to argue that the type of support evidenced in Nicaragua and the Bosnian Genocide case (including logistical support, providing munitions, tactical training and target selection), when provided for terrorist activities, does not necessarily imply support for the crimes committed by the terrorists in the course of their use of force. There is therefore no need for the added layer of effective control (in the form of the supporting state's boots on the ground or active direction during the operation), in addition to a more general level of control over the group's operations (through its support thereof), to ensure that a state is only held responsible for its

\footnotetext{
${ }^{33}$ See e.g. Bayindir Insaat Turizm Ve Sanayi AS v. Islamic Republic of Pakistan, ICSID Case No. ARB/03/29, Award, 27 August 2009, para. 130.

${ }^{34}$ Military and Paramilitary Activities in and against Nicaragua (Nicaragua v. United States of America), Merits, ICJ Reports 1986, p. 14.

${ }^{35}$ The Court held that Article 8 of the ARSIWA must be 'understood in the light of the Court's [decision in Nicaragua]' (Bosnian Genocide case, para. 399), rendering 'effective control' the exclusive standard of control under Article 8 (ibid., para. 400).

${ }^{36}$ Emphasis added. Nicaragua, para. 115. Given the level of US and Serbian support for the 'contras' and VRS respectively, including training, supplying and target selection (see Nicaragua, paras. 101-102, 106, 108; Bosnian Genocide case, paras. 238-241, 388), one might conclude that the only way effective control might have been established for the purposes of attribution is if there had been American or Serbian troops on the ground with the contras or the VRS (or at least exercising operational control via radio) during the paramilitary operations in the course of which war crimes or genocide were committed.
} 
own conduct.

As it stands, state support for terrorism, no matter how substantial, will not generally satisfy the 'effective control' test as articulated by the ICJ. In his study of state terrorism, Byman concludes that the most common forms of support for NSTAs are training (in explosives particularly), the provision of intelligence, the supply of arms, financing, the provision of logistical assistance (for example issuing passports and helping terrorist actors obtain visas through state fronted companies or non-governmental organisations), ideological direction and sanctuary. ${ }^{37}$ While states often support terrorist activities by offering several or indeed all of these forms of support, ${ }^{38}$ together they do not satisfy the effective control test in Nicaragua.

The answer to these difficulties is simply that the rules of attribution should not be applied so strictly as to deny the reality of state participation in terrorism. A flexible and contextsensitive approach to the application of Article 8 of the Articles on State Responsibility, which incorporates something like the 'overall control' standard set forth in the ICTY's Tadić decision, ${ }^{39}$ is all that is required to respond to this difficulty.

But even in the absence of the attributability of terrorist acts, a state's failure to act in response to acts of terrorism - whether before the fact (in the form of a failure to prevent) or after the fact (in the form of a failure to punish) - might still amount to an internationally wrongful act for which that state bears responsibility. The next sections consider some of the difficulties in the practical application of the primary rules of international law addressing terrorism, which limit the possibilities for state responsibility (and consequently shared responsibility) in the terrorism context.

\footnotetext{
${ }^{37}$ Byman 2005, p. 54-66.

${ }^{38}$ Byman 2005, p. 54.

39 Prosecutor v. Tadić, Judgment, ICTY Case No IT-94-1-A, 15 July 1999, para. 120. Relevant degrees of control might also be adjudged on the basis of the state's capacity to prevent the relevant conduct (see The Netherlands v. Hasan Nuhanović, ECLI:NL:HR:2013:BZ9225 (6 September 2013), available at www.rechtspraak.nl/Organisatie/Hoge-Raad/OverDeHogeRaad/publicaties/Documents/12\%2003324.pdf). In regard to non-inherent features of military operations, such a standard might well deliver the same result as the effective control standard in Nicaragua, but would respond better to the factual matrix of terrorist operations (where the crime is inherent in the use of force) by recognising attribution in cases where the state's overall control extended to its capacity to call off attacks.
} 


\subsection{Shared responsibility for state failures to prevent un-attributable terrorist acts}

State act B in the matrix above details the second possible case of shared responsibility for a single act of terrorism - which responsibility is based on the independent acts of different sets of actors contributing to a single harmful outcome and arises as a result of the breach of different norms by those actors. The starting point is un-attributable terrorist conduct (for which conduct an individual non-state actor can be held criminally responsible). Shared responsibility results where the state is also delictually responsible for its failure to act appropriately in relation to terrorist conduct before the fact - through a failure to diligently prevent terrorism. ${ }^{40}$ But as set out in the matrix in section 2, not every failure to prevent acts of terrorism results in shared responsibility. It is entirely possible for a state to factually fail to prevent an act of terrorism, for which failure it is not legally responsible. In such cases, there may well be individual criminal responsibility without any state responsibility - and therefore no shared responsibility either.

Customary international law and the TSCs require states to prevent acts of trans-national terrorism, ${ }^{41}$ which obligation is conditioned by territoriality ${ }^{42}$ and a due diligence standard of conduct. ${ }^{43}$ Yet despite there being some fairly evident failures to act in the prevention of terrorism, often put in evidence through more active forms of complicity, the TSCs (which have strong ratification and have compromissory clauses conferring jurisdiction on the ICJ) ${ }^{44}$ have yet to be successfully invoked as a basis of state responsibility for a failure to prevent trans-national terrorism. The only case before the ICJ in which the obligation of prevention under a TSC was asserted as a basis of state responsibility was the Tehran Hostages case. ${ }^{45}$ Given the other bases for Iranian responsibility, in particular the Vienna Conventions on Diplomatic and Consular Relations, the Court did not 'find it necessary ... to enter into the

\footnotetext{
${ }^{40}$ See below n. 43.

${ }^{41}$ On the customary obligation to prevent, see Corfu Channel case, p. 22 and the ILC's survey of international law in relation to its work of codification, UN Doc. A/CN.4/1/Rev.1 (1949), 56, para. 97 (referring to 'failures to prevent the use of national territory as a base for acts noxious to the legitimate interests of neighbouring States' as one of the central problems of state responsibility calling for elucidation). On the TSC obligation to prevent, see e.g. Article 15 Terrorist Bombing Convention; Article 18 Terrorism Financing Convention.

42 The TSCs each require states to take all practicable measures to 'prevent and counter preparations in their respective territories for the commission' of the defined terrorist offences. See e.g. Article 15 Terrorist Bombing Convention; Article 18 Terrorism Financing Convention (emphasis added).

${ }^{43}$ Diligent prevention is evaluated in light of what the state knew (or ought to have known) about the threat emanating from its territory, and its genuine capacity to avert the threat. See Trapp 2011, §3.1.

${ }^{44}$ See e.g. Article 20 Terrorist Bombing Convention; Article 24 Terrorism Financing Convention.

${ }^{45}$ United States Diplomatic and Consular Staff in Tehran (United States of America v. Islamic Republic of Iran), Memorial of the Government of the United States, Pleadings, Oral Arguments, Documents, Volume 1, p. 123, pp. 176-178. United States Diplomatic and Consular Staff in Tehran (United States of America v. Iran), Judgment, ICJ Reports 1980, p. 3 (Tehran Hostages case).
} 
question whether, in the particular circumstances of the case, Article 13 of [the International Protected Persons] Convention provides a basis for the exercise of the Court's jurisdiction with respect to those claims'. ${ }^{46}$

There are a number of possible reasons for the failure to make the jump from a binding obligation of prevention to successful invocations of state responsibility in the terrorism context (which responsibility would give effect to the shared responsibility of NSTAs and states in cases of individual prosecution), the most intractable of which is explored below.

\subsubsection{Failed or weak states}

Failed or weak states pose a particularly difficult problem in regard to terrorism prevention. Such states lack the general capacity, resources or territorial control that is a factual prerequisite for effective counter-terrorism measures, yet it is by that very fact that they are the ideal safe haven for terrorist groups. ${ }^{47}$ With the TSC focus on territorial prevention, such capacity and territorial control is also a legal pre-requisite for a finding of responsibility. ${ }^{48}$ The ICJ emphasised in both Corfu Channel and the Tehran Hostages case that international responsibility for a failure to prevent depends both on a state's knowing that there was a need to take preventive measures, and on the state's having the means available with which to comply with its prevention obligations. ${ }^{49}$ The Counter-Terrorism Committee created pursuant to Security Council Resolution 1373 (2001) has engaged in a capacity building blitz the likes of which the international community has never before seen, but there continue to be a number of states which do not exercise the necessary control over the entirety of their territories for the purposes of putting developed counter-terrorism capacity to good use. ${ }^{50}$

While weak or failed states are the states we most want to see diligently exercise their

\footnotetext{
${ }^{46}$ Tehran Hostages case, para. 55.

${ }^{47}$ See Byman 2005.

${ }^{48}$ The obligation to prevent terrorism is one of diligence, not of result. See Lillich and Paxman 1977, pp. 309310; Condorelli 1989, pp. 240-241; and International Law Association, Report of the sixty-first conference, Paris, 1984, pp. 140-141. International case law and doctrine have long held that capacity (or rather incapacity) is the limit of legal responsibility. See e.g. Jamaica case (Great Britain/United States of America) (1798), in Moore 1898, p. 3983, p. 3990-91. Much more recently, see Bosnian Genocide case, para. 430.

${ }^{49}$ Corfu Channel case, p. 23; Tehran Hostages case, p. 33.

50 See US Department of State (Office of the Coordinator for Counterterrorism), Country Reports on Terrorism 2013, www.state.gov/j/ct/rls/crt/2013/index.htm, chapter 5, discussing long unguarded coastline, porous borders, and proximity to the Arabian Peninsula in Somalia; widely spread islands in the Sulu Archipelago; difficult terrain in the Afghan and Pakistan border regions; and rough terrain and dense forest cover, coupled with low population densities in Colombia, as factors which contribute to the emergence of terrorist safe havens.
} 
counter-terrorism obligations, they are also the states which are least likely to meet the criteria for being held legally responsible for failing to prevent. Such a finding of legal responsibility would in any case almost certainly be counter-productive (as any damages awarded against a weak and wrongdoing state for its failure to prevent would further detract from the resources it has available to put into counter-terrorism). ${ }^{51}$ The counter-terrorism challenges these states pose are arguably more a question of political will, and the emerging interdependence of development and international security, ${ }^{52}$ than legal responsibility - shared or otherwise.

\subsubsection{An alternative to territorially limited prevention obligations?}

A different approach to prevention in the terrorism context may be called for - one which responds to the trans-national nature of terrorist activity and emphasises the co-operative feature of the obligation to prevent, in lieu of its territoriality. ${ }^{53}$ The obligation to prevent, as it is framed in the TSCs, over-emphasises the role of the territorial state (which may be a failed or weak state) and obscures the role non-territorial states might play in prevention. An approach focused on co-operation instead of territoriality could helpfully draw on the ICJ's decision in the Bosnian Genocide case (even bearing in mind the Court's warnings that its pronouncements were not a code on prevention generally, but were rather carefully tailored comments on the Genocide Convention) $)^{54}$ - in which the Court adopted a 'sphere of influence' approach to prevention. ${ }^{55}$ The Court in effect recognised that states which support extra-territorial conduct (even when that conduct cannot be tied to the state through the legal fiction of attribution) are thereby failing to prevent that conduct, because they are failing to use the influence inherent in their material support of NSTAs to prevent international crimes.

\footnotetext{
${ }^{51}$ This said, a moderate damages award (a one-off cost) against a state which is further along the development index might prompt it to change its spending priorities, and to give more money to anti-terrorist efforts (as an ongoing matter).

52 Report of the High Level Panel on Threats, Challenges and Change, 'A More Secure World: Our Shared Responsibility’, UN Doc. A/59/565 (2004); 2005 World Summit Outcome Document, UN Doc. A/RES/60/1 (24 October 2005).

${ }^{53}$ The obligation to prevent terrorism in the TSCs is both territorially limited and focused on co-operation. For example, Article 15 of the Terrorist Bombing Convention requires states to 'cooperate in the prevention of the offences set forth in article 2, particularly [... by] prevent[ing] and counter[ing] preparations in their respective territories for the commission of those offences within or outside their territories' (emphasis added). These are not necessarily entirely consistent approaches to prevention - the first tying prevention efforts to a particular state's territory (over which only the territorial state will have jurisdiction), the second recognising that the transnational nature of terrorist conduct requires a multi-state approach.

${ }^{54}$ Bosnian Genocide case, para. 429. Convention on the Prevention and Punishment of the Crime of Genocide, Paris, 9 December 1948, in force 12 January 1951, 78 UNTS 277 (Genocide Convention).

${ }^{55}$ Bosnian Genocide case, para. 430.
} 
Such an approach has obvious appeal in the terrorism context given that state support for terrorism (both material and rhetorical) can rarely be tied directly to a particular terrorist act, but would certainly meet a general 'sphere of influence' standard, with failures to exercise such influence triggering legal responsibility. The result of such an approach to terrorism prevention would be to open up the possibilities for giving effect to shared responsibility recognising the factual role that states play in facilitating acts of individual terrorism through the application of a responsibility framework, without inappropriately catching states which could not but do otherwise (failed or weak states) in the shared responsibility web.

\subsection{The problem with aut dedere aut judicare - a recipe for no responsibility at all}

State act C in the section 2 matrix details the third possible case of shared responsibility for a single act of terrorism - which responsibility is again based on the independent acts of different sets of actors contributing to a single harmful outcome (in this case impunity for terrorism) and arises as a result of the breach of different norms by those actors. As with section 3.2 above, the starting point is un-attributable terrorist conduct (for which conduct an individual non-state actor should be held criminally responsible). Shared responsibility results where the state is delictually responsible for its failure to act appropriately in relation to terrorist conduct after the fact - through a failure to extradite or prosecute a terrorist actor. But as set out in the matrix in section 2, not every failure to extradite or prosecute an act of terrorism results in shared responsibility. It is entirely possible for a state to factually fail to punish an act of terrorism, for which failure it is not legally responsible. For the reasons explored below, where the terrorist actor is in the territory of the state failing to meet its criminal law enforcement obligations, and where that failure is not one for which the state can be held legally responsible - the result is no responsibility at all: no legal responsibility on the part of a state, which translates into no criminal responsibility for NSTAs (although in a practical, rather than legal sense).

The TSC obligation to establish prescriptive jurisdiction over defined terrorist offences, ${ }^{56}$

\footnotetext{
${ }^{56}$ Under the TSCs, a state is required to establish its prescriptive jurisdiction on the basis of the territoriality and nationality principles, and in some cases is permitted to establish jurisdiction on the basis of passive personality and the effects doctrine. See e.g. Article 6 Terrorist Bombing Convention. A state is also required to 'establish ... jurisdiction over the [defined terrorist] offences in cases where the alleged offender is present in its territory and it does not extradite that person to any of the States Parties which have established their jurisdiction [on the basis of the territoriality or nationality principles]'. In order to meet this latter obligation (coupled with the aut
} 
coupled with an aut dedere aut judicare obligation, ${ }^{57}$ is intended to cover the field of possible jurisdictional difficulties a prosecution for trans-national terrorism might encounter. In particular, the TSCs were drafted to respond to the possibility that an alleged terrorist is in the territory of a state which otherwise has no connection with the crime or victims, but for whom extradition is impossible given the lack of a relevant treaty framework, an applicable exception to extradition, or because non-refoulement obligations attach to the state or states which might otherwise exercise criminal jurisdiction. But the aut dedere aut judicare obligation in the TSCs is also framed in a way that is sensitive to the practical difficulties of trans-national terrorism prosecutions - and this limits the extent to which the TSCs can be effective instruments for ensuring that there is no impunity for terrorist offences.

The aut dedere aut judicare obligation in the TSCs is framed in almost precisely the same terms as that under the Convention against Torture ${ }^{58}$, which was the subject of a recent judgment by the ICJ. In its Belgium v. Senegal decision, the Court rightly held that a state's obligation to submit to prosecution (which is triggered by the presence of an alleged offender in its territory) is conditional on non-extradition, but that extradition itself is framed in optional (not obligatory) terms. ${ }^{59}$ Precisely the same is true of the aut dedere aut judicare obligation in the TSCs. Where an extradition request is made, there is nothing in the formulation of the aut dedere aut judicare obligation in the TSCs which requires the requested state to accede thereto. ${ }^{60}$

But where a state refuses to extradite, for whatever reason, it is thereby placed in the same position as a custodial state to which no extradition request has been made - it is under an obligation to submit the case to its competent authorities for prosecution. Such an obligation does not, of course, require that a prosecution in fact take place. All that is required of a state

dedere aut judicare obligation, below n. 577), states must establish jurisdiction on a universal basis - as that is the only way they will be in a position to prosecute (in default of extradition) in cases where the terrorist act was committed extra-territorially and the custodial state has no connection to the terrorist actor, crime or victims thereof.

${ }^{57}$ See e.g. Article 8 Terrorist Bombing Convention; Article 10 Terrorism Financing Convention.

${ }^{58}$ Convention Against Torture and Other Cruel, Inhuman or Degrading Treatment or Punishment, New York, 10 December 1984, in force 26 June 1987, 1465 UNTS 85 (Convention against Torture).

${ }^{59}$ Questions relating to the Obligation to Prosecute or Extradite (Belgium v. Senegal), Judgment, ICJ Reports 2012, p. 422, paras. 92-95 (Belgium v. Senegal).

${ }^{60}$ For instance, a state for which extradition is conditional on the existence of a treaty 'may at its option consider the [relevant TSC] as the legal basis for extradition', and extradition is further subject to the conditions provided for by the law of the requested state. Emphasis added, Article 9 Terrorist Bombing Convention; Article 11 Terrorism Financing Convention. See further Questions of Interpretation and Application of the 1971 Montreal Convention arising from the Aerial Incident at Lockerbie (Libyan Arab Jamahiriya v. United Kingdom), Provisional Measures, Order of 14 April 1992, ICJ Reports 2012 p. 3, Joint Decision of Judges Evensen, Tarassov, Guillaume and Aguilar Mawdsley, para. 3. 
is that it put its criminal law enforcement machinery at the disposal of terrorism prosecutions in good faith ${ }^{61}$ without regard to the expense of any eventual criminal proceedings, ${ }^{62}$ and that it be in a position to justify decisions not to mount a prosecution on objective grounds. The Committee Against Torture held that if there was insufficient evidence to prosecute, a refusal to do so (even in the absence of an extradition request to which the requesting state accedes) would not amount to a breach of the aut dedere aut judicare obligation under the Convention against Torture. ${ }^{63}$ While the decision does not necessarily suggest that if there is sufficient evidence, a refusal to prosecute will amount to a breach of the aut dedere aut judicare obligation, it does account for the practical difficulties involved in mounting a trans-national terrorism prosecution and suggests that a decision not to prosecute should at least be justifiable on objective grounds. ${ }^{64}$

That said, given the nature of terrorist crimes - in particular the secrecy with which they are planned and carried out and their trans-national component (which seriously complicates evidence collection) - there will often be objective reasons for a decision not to put public resources at the disposal of a terrorism prosecution (particularly in the case where jurisdiction is exercised on a universal basis). That the availability of objective reasons for not mounting a prosecution coincides with a custodial state's reticence to prosecute (for financial reasons or sympathy with the cause of relevant terrorist actors) will of course not deprive those reasons of their capacity to shield the custodial state from responsibility. Given that states are under no obligation to grant a request for extradition under the TSCs, the wide margin of prosecutorial discretion recognised in the TSCs potentially undermines the 'no impunity' objective of their aut dedere aut judicare obligation - in that such failures to prosecute will of course result in no practical responsibility for the NSTA (even if that NSTA did in fact

\footnotetext{
${ }^{61}$ The aut dedere aut judicare obligation in the TSCs requires that competent authorities take their decision 'to prosecute or not to prosecute' in the same manner as in the case of any other offence of a grave nature. See e.g. Article 8(1) Terrorist Bombing Convention. At the very least, this will require a good faith intention to effectively implement the criminal law enforcement obligations of the TSCs.

${ }^{62}$ In regard to the subject of the Belgium v. Senegal proceedings, Senegal claimed that it could not extradite $\mathrm{Mr}$ Habré to Belgium see Guengueng et al v. Senegal, Committee against Torture, Decision of 19 May 2006, UN Doc. CAT/C/36/D/181/2001, para. 9.4 (Guengueng et al v. Senegal), and that it intended to submit Mr Habré's case to its prosecutorial authorities on receipt of EUR 27.4 million in international funding for all the costs of a trial (Human Rights Watch, AU: Push Senegal to Try Habré, 29 June 2009, www.hrw.org/en/news/2009/06/29/au-push-senegal-try-habr). The ICJ held that 'the financial difficulties raised by Senegal cannot justify the fact that it failed to initiate proceedings against Mr. Habré'. Belgium v. Senegal, para. 112.

${ }^{63}$ Guengueng et al v. Senegal, para. 9.8.

${ }^{64}$ Courts have tended to consider whether there is indeed any objective basis for a decision not to prosecute. See Belgium v. Senegal, para. 94; The Chili Komitee Nederland (CKN, Dutch branch of the Chile Committee) v. Public Prosecutor, Court of Appeal of Amsterdam, 4 January 1995, reported in (1997) Netherlands YbIL 28: 363.
} 
commit the act of terrorism and is therefore legally responsibility). And where the failure to prosecute (if objective justifications are available) does not engage the state's responsibility either, there is no prospect for the effective implementation of shared responsibility.

The TSCs, however, are not without a tool-kit to address the complications inherent in transnational criminal prosecutions. In particular, each imposes mutual legal assistance obligations $^{65}$ - a serious commitment to which would go a long way towards ensuring that there are no objective reasons for refusing to exercise prosecutorial discretion in favour of bringing alleged terrorists to justice. A failure to prosecute in the absence of any such objective reasons would of course give rise to a state's responsibility for a failure to meet its aut dedere aut judicare obligation, implementation of which responsibility (in particular through the secondary obligation to cease the wrongful conduct) would then give practical effect (at least potentially) to individual criminal responsibility, and as a result, shared responsibility.

\section{Conclusions}

The international community's response to the threat of trans-national terrorism in part treats the state itself as a potential terrorist actor (within a jus ad bellum framework), and in part treats the state as the mechanism of control through which NSTA conduct is addressed. As a result, states are under primary obligations to both refrain from engaging in terrorist conduct on the one hand, and to prevent acts of terrorism by NSTAs, criminalise and punish any such acts which are not successfully prevented on the other. Trans-national terrorism is therefore a phenomenon which straddles the different frameworks of responsibility under international law - individual criminal and state responsibility - and gives rise to the possibility of shared responsibility.

That said, giving effect to shared responsibility in the terrorism context depends on the strength of these component frameworks of responsibility. For a variety of reasons, some of which were explored above, those component parts are not as strong as they might be. While the reflex response to grotesquely savage terrorist attacks tends to focus on criminal justice, some notorious cases of state sponsored or supported terrorism have resulted in heavy

\footnotetext{
${ }^{65}$ See e.g. Article 10 Terrorist Bombing Convention; Article 12 Terrorism Financing Convention.
} 
reparation payments by the (allegedly) wrongdoing state ${ }^{66}$ - emphasising the relevance of a shared responsibility approach. A shared responsibility project in the terrorism context is, however, not without its difficulties. Some of these difficulties, like those regarding the standard of attribution (examined in section 3.1 above), are easily enough addressed with flexibility, the eschewal of a slavish commitment to inapposite precedent, and a 'transnational terrorism context sensitive' approach to both primary and secondary rules of international law.

Other challenges, like those presented by failed or weak states to successful terrorism prevention, are less easily addressed through tinkering with the applicable legal framework. Indeed such tinkering could be counter-productive in that making it possible to hold failed or weak states responsible for factual failures to prevent terrorism would further undermine their already reduced capacity to successfully participate in the 'war on terror'. As states increasingly recognise the interdependence of development and international security, and genuinely engage in capacity building endeavours so as to shore up the terrorism prevention capabilities of weak states, the need for a shared responsibility framework should decrease at least in respect of incapacity driven failures to prevent.

And still other issues explored above emphasise the extent to which the different forms of responsibility under international law are co-dependent. Individual and state responsibility as applied in the terrorism context are not only potentially shared, they are mutually reinforcing. For instance, the framework of state responsibility could have an important role to play in holding states to their criminal law enforcement obligations - which will of course have its own positive effect on a 'no impunity' project and ensuring NSTAs are held individually

\footnotetext{
${ }^{66}$ Following the conviction of Libyan secret service agent and embassy workers for the La Belle Disco bombing (1986) by German courts, Libya agreed to pay USD35 million in compensation for non-US victims of the La Belle bombing. See 'Libya inks \$35m Berlin bomb deal', BBC, 3 September 2004, available at http://news.bbc.co.uk/2/hi/europe/3625756.stm. France paid New Zealand compensation for its sponsorship of the Rainbow Warrior bombing following the confessions of French secret service agents Mafart and Prieur. United Nations Secretary General, Ruling Pertaining to the Differences between France and New Zealand Arising from the Rainbow Warrior Affair, 6 July 1986, XIX RIAA 199 (Rainbow Warrior). Perhaps most famously, following the 2001 conviction of Ali Mohamed Al Megrahi (a Libyan secret service agent) by a Scottish court sitting in the Hague, Libya paid compensation to US and UK victims of the Lockerbie bombing although Libya's ultimate acceptance of 'civil responsibility' under international law for the bombing was most likely the result of fatigue from the prolonged Security Council sanctions regime to which it was subject. In an interview with the BBC, Colonel Gaddafi's son suggested that the Libyan government had only accepted responsibility for the Lockerbie bombing in order to have international sanctions lifted. He confessed that: 'Yes, we wrote a letter to the Security Council saying we are responsible for the acts of our employees ... but it doesn't mean that we did it in fact ... I admit that we played with words - we had to ... What can you do? Without writing that letter we would not be able to get rid of sanctions.' 'Lockerbie evidence not disclosed', BBC, 28 August 2008, available at http://news.bbc.co.uk/1/hi/scotland/south_of_scotland/7573244.stm.
} 
responsible for their terrorist crimes. ${ }^{67}$ In light of this co-dependence, successful implementation of shared responsibility for terrorism calls for a serious commitment to certain primary rules (for instance in the form of mutual legal assistance, as detailed in section 3.3 above). There is also considerable scope to exploit the increasing engagement between domestic and international courts in furtherance of a shared responsibility project in the terrorism context. Given the international community's reflexive reliance on a criminal law enforcement paradigm, and the catalysing effect domestic criminal convictions can have on invocations of state responsibility for terrorism, ${ }^{68}$ a robust application of the aut dedere aut judicare obligation would ensure not only that there is no impunity for terrorist crimes, but also that shared responsibility is given effect to where relevant.

\footnotetext{
${ }^{67}$ International law is not yet at a stage where individual criminal responsibility can be imposed without the active participation of states. But see Trapp 2011, §6.4.3, regarding the potential availability of the International Criminal Court for terrorism prosecutions.

${ }^{68}$ See above n. 66.
} 


\section{Reference list}

Bílková V (2015) Armed Opposition Groups and Shared Responsibility. Netherlands International Law Review 62:YY-ZZ

Byman D (2005) Deadly Connections: States that Sponsor Terrorism. Cambridge University Press, Cambridge

Condorelli L (1989) The Imputability to States of Acts of International Terrorism. Israel Yearbook of Human Rights 19: 233-246

Crawford JR (2002) The International Law Commission's Articles on State Responsibility: Introduction, Text and Commentaries. Cambridge University Press, Cambridge

Crawford JR (2010) International Crimes of States. In: Crawford JR et al. (eds) The Law of International Responsibility. Oxford University Press, Oxford, pp 405-414

D’Aspremont J, Nollkaemper PA, Plakokefalos I, Ryngaert C (2015) Sharing Responsibility between Non-State Actors and States in International Law: Introduction. Netherlands International Law Review 62:YY-ZZ

Dupuy P-M (2004) State Sponsors of Terrorism: Issues of International Responsibility. In: Bianchi A (ed) Enforcing International Law Norms Against Terrorism. Hart Publishing, Oxford, pp 1-16

Hoffman B (2006) Inside Terrorism. Columbia University Press, New York

Jørgensen NHB (2000) The Responsibility of States for International Crimes. Oxford University Press, Oxford

Karavias M (2015) Shared Responsibility and Multinational Enterprises. Netherlands International Law Review 62:YY-ZZ

Lillich RB, Paxman JM (1977) State Responsibility for Injuries to Aliens Occasioned by Terrorist Activities. American University Law Review 26: 217-313

MacLeod S (2015) Private Security Companies and Shared Responsibility: The Turn to Multistakeholder Standard-Setting and Monitoring through Self-Regulation-'Plus’.

Netherlands International Law Review 62:YY-ZZ

Moore JB (ed) (1898) History and digest of international arbitrations to which the United States has been a Party, Volume 4, p. 3983

Nollkaemper PA (2008) Multi-level Accountability: A Case Study of Accountability in the Aftermath of the Srebrenica Massacre. In: Broude T, Shany Y (eds) The Shifting Allocation of Authority in International Law. Hart Publishing, Oxford, pp 345-638

Pellet A (1999) Can a State Commit a Crime? Definitely, Yes! European Journal of International Law 10: 425-434 
Pellet A (2010) The Definition of Responsibility in International Law. In: Crawford JR et al. (eds) The Law of International Responsibility. Oxford University Press, Oxford, pp 3-16

Trapp KN (2011) State Responsibility for International Terrorism. Oxford University Press, Oxford

Trapp KN (2012) Holding States Responsible for Terrorism before the International Court of Justice'. Journal of International Dispute Settlement 3: 279-298

Trapp KN (2014) The Interaction of the International Terrorism Suppression Regime and IHL in Domestic Criminal Prosecutions: The UK Experience. In: Jinks D et al. (eds) Applying International Humanitarian Law in Judicial and Quasi-Jjudicial Bodies: International and Domestic Aspects, TMC Asser Press, The Hague, pp 165-182 